\title{
2.6 Система підготовки педагогічних працівників у Канаді
}

Вдосконалення педагогічної освіти привертає увагу політиків та науковців усіх розвинутих країн світу. Цікавим є досвід організації формування майбутніх вчителів в Канаді, адже, по-перше, в цій країни система вищої освіти швидко реагує на всі зміни, які відбуваються у суспільстві, по-друге, професія вчителя в Канаді має суттєвий соціальний статус, що обумовлює високий прохідний бал для вступу на педагогічні спеціальності та грунтовну підготовку абітурієнтів. Розглядаючи систему підготовки майбутніх вчителів в Канаді, необхідно враховувати той факт, що Канада є федеративною державою, тому в країні не існує єдиного підходу до підготовки спеціалістів. На систему підготовки майбутніх спеціалістів впливають соціально-культурні реалії та особливості кожного окремого регіону. До того ж, заклади освіти Канади мають значну автономію у формуванні освітніх програм [77].

Освіта в Канаді є дуже високим пріоритетом уряду. Країна може пишатися системою державної освіти, яка забезпечується, фінансується та керується федеральними, провінційними та місцевими органами влади. Юрисдикція системи державної освіти, а також іï навчальний план контролюється кожною провінцією. Рада міністрів освіти є форумом для міністрів освіти з обговорення питань, пов’язаних з освітою, координацією освітньої діяльності та обміном інформації.

У кожній провінції існує свій власний Департамент чи Міністерство освіти. Центральним органом управління освітою є Міністр освіти. У деяких провінціях вища освіта та навчання підпорядковуються окремому міністру та департаменту, тоді як в інших - обидві галузі включені в одну юрисдикцію. Міністр освіти, виборний член законодавчого органу провінції, призначається до освітнього портфеля Прем'єр-міністром; він або вона також є членом Кабінету Міністрів. У канадській парламентській системі Кабінет Міністрів відповідальний перед законодавчими органами та залежить від підтримки більшості його членів, а 
також є ключовим органом планування та керівництва Урядом. Він визначає, які закони висуваються Урядом,

Роль, яку виконує Міністр освіти у будь-який конкретний період часу, залежить від загальних пріоритетів Прем'єр-міністра та Уряду, а також від здатності міністра впливати на ці пріоритети. Міністри приймають або затверджують рішення з усіх видів освіти: від нових навчальних планів, які мають бути введені, правил, що регулюють атестацію вчителів, до кількості кредитів, необхідних для закінчення середньої школи. Міністр повинен захищати перед суспільством політику Уряду щодо освіти, навіть якщо він чи вона виступає проти цієї політики. I коли сторони в місцевому спорі на рівні шкільної ради чи району не можуть дійти згоди, вони часто закликають Міністра втрутитися і вирішити суперечливе питання.

Державну службу департаменту очолює Заступник міністра, який $є$ державним службовцем, що призначається Кабінетом Міністрів. Свого часу провінційні Заступники міністра майже завжди мали педагогічну освіту та досвід, багато з яких раніше були вчителями, директорами та шкільними інспекторами. Заступник міністра координує роботу департаменту за всіма його функціями. Типовий Відділ освіти має підрозділи, які займаються такими сферами, як планування, фінансування шкіл, розробка та оцінювання навчальних програм, спеціальна освіта, мовні програми та ремонт і будівництво шкільних споруд. Усі ці завдання вимагають постійної уваги та певного технічного досвіду; таким чином, сьогодні Відділи освіти, як правило, є великими організаціями, в яких працюють сотні людей, багато 3 яких є професійними педагогами .

Департамент освіти є поєднанням політичної і професійної влади, який втілює контроль якості освіти. Державні службовці, як правило, керуються своєю професійною підготовкою та педагогічною освітою. Їх погляди на потреби освіти часто схожі на погляди вчителів у школах. Ця напруженість є частиною процесу управління і може сприяти розробці політики, яка враховує як професійні навички, так і потреби суспільства [78, с. 34] 
Необхідно зазначити, що освітні програми для вчителів в Канаді значно відрізняються одна від одної як за тривалістю, так і за кількістю студентів. В залежності від університету та освітньої програми кількість випускників може бути від 30 до 1200 на рік. До освітніх програм, які користуються найбільшою популярністю можна віднести підготовку вчителів для викладання різних дисциплін у середній та старшій школі (математика, іноземна мова, хімія, біологія, фізичне виховання) та вчителів молодшої школи. Дещо меншою популярністю серед здобувачів освіти користуються освітні програми, спрямовані на підготовку дітей дошкільного віку, вчителів для корінного населення, педагогів для роботи з дорослим населенням та фахівців з лікувальної педагогіки [79, с. 24].

На основі аналізу педагогічної літератури можна стверджувати, що формування майбутніх вчителів в Канаді здебільше відбувається за паралельною (concurrent) та послідовною (consecutive) моделлю освіти. Паралельна модель освіти включає програму подвійного диплому. Тривалість навчання за такими програмами складає від чотирьох до шести років. Навчаючись в університеті студенти паралельно вивчають спеціальні дисципліни та дисципліни психологопедагогічного блоку, які дозволяють здійснювати викладацьку діяльність. Після закінчення навчання студенти отримують подвійний диплом: за спеціальністю, які вони вивчали, та диплом з педагогіки (Bachelor of Education) [77, с. 2, с. 4, с. 5]. Наприклад, в Королівському університеті в Кінгстоні, який розташовано у провінції Онтаріо, випускники педагогічного університету отримують диплом спеціаліста у галузі мистецтва, музики або природничих наук та диплом 3 педагогіки [82].

Послідовна модель освіти побудована іншим чином. Спочатку студенти отримують ступінь бакалавру 3 природничого або гуманітарного профілю (бакалавр мистецтва - B.A. або бакалавр наук - B.Sc), а вже після цього навчаються за освітньою програмою професійної педагогічної підготовки, тривалість якої може бути від декількох семестрів до двох років [83, с. 211]. 
Прикладом послідовної моделі освіти може бути педагогічний факультет Університету Оттави (провінція Онтаріо). Цей університет $\epsilon$ одним із найбільших двомовних університетів не тільки в Канаді, але й в усьому світі. Процес навчання забезпечується як англійською, так і французькою мовами. Для того, щоб вступити до педагогічного університету, студентам спочатку необхідно закінчити навчання за будь-якою іншою програмою бакалаврського рівня не менше, ніж три роки. Навчання на педагогічному факультеті триває два роки, після чого здобувачі освіти отримують ступень бакалавра з педагогіки та можуть працювати вчителем початкової або середньої школи або вчителем іноземної мови в залежності від обраної спеціалізації. У рамках цієї моделі навчання, навчаючись на педагогічному факультеті, студенти переважно вивчають основи педагогіки та методику викладання, а також проходять практику на базі шкіл під керівництвом досвідчених менторів.

Третьою моделлю педагогічної освіти, яка здебільше застосовується в французькій провінції Квебек, є так звана єдина модель (sole model). Ця модель освіти дуже схожа на паралельну, але відмінністю $є$ те, що студент отримує тільки один диплом - бакалавра педагогіки. Ще однією особливістю цієї моделі $€$ велика кількість годин, що відводиться на проходження педагогічної практики: 700 годин або 20 відсотків загального навантаження освітньої програми [83, с. 212].

Отже, підсумовуючи, можна зазначити, що кожна із моделей має свої переваги та недоліки. Так, навчаючись за послідовною моделлю освіти із подвійним дипломом, студенти мають більше можливостей для працевлаштування, але разом із тим, практична педагогічна складова їх підготовки $\epsilon$ не така грунтовна, як у тих, хто навчається за паралельною або єдиною моделями. Перевагою послідовної моделі є грунтовна фундаментальна підготовка із знань за фахом. До того ж, вже до вступу на педагогічний факультет студенти мають не тільки знання за фахом, але й певний особистий та професійний досвід, що дозволяє сприймати та аналізувати інформацію 3 позицій зрілої особистості. 
Так, у Британській Колумбії існують досить суворі вимоги до здійснення педагогічної діяльності. На території провінції функціонує професійна організація, Коледж вчителів Британської Колумбії (BC College of Teachers), які визначає критерії вимог, що висуваються до сертифікації вчителів. Для акредитації освітніх програм заклади вищої освіти штату мають узгодити їх із Коледжем та довести, що їх програми відповідають восьми стандартам, які $є$ обов'язковими для цього штату.

До основних видів діяльності Коледжу вчителів Британської Колумбії можна віднести організацію та проведення моніторингу серед студентів, викладачів та випускників педагогічних університету штату, аналіз непрофесійної поведінки вчителів та дисциплінарні слухання, сертифікація вчителів $[84$, с. 76$]$.

Найбільшим університетом, який здійснює підготовку педагогічних кадрів, є Університет Британської Колумбії, який було створено понад 60 років тому. Щорічно в університеті виконується близько 4 тис. досліджень, загальний їх бюджет становить 250 млн. Таким чином, університет має відношення до 60\% всіх досліджень, що проводяться в провінції Британська Колумбія. Університет Британської Колумбії відомий в академічному середовищі завдяки своїм інноваційним дослідженням і досягненням не лише у галузі науки і освіти, а також і в інших сферах. Він входить в список кращих навчальних закладів світу, а його престиж дозволяє запрошувати висококваліфікованих фахівців. Також університет Британської Колумбії співпрацює з іншими навчальними закладами на міжнародному рівні. Факультет освіти та виховання (Education Faculty) $\epsilon$ найбільшим факультетом провінції Британська Колумбія та відіграє важливу роль у розвитку освіти регіону, формуючи можливості та потенціал освіти як соціального блага.

На факультеті освіти та виховання здійснюється підготовка близько $45 \%$ вчителів початкової та середньої освіти в Британській Колумбії, а також значну частину шкільних радників, адміністраторів, спеціалістів із спеціальної освіти та 
шкільних психологів Британської Колумбії. За роки свого існування факультет підготував більше 50 тисяч випускників, які працюють у 100 країнах світу.

На факультеті створено умови для організації навчального процесу за допомогою інноваційних технологій із використанням результатів передових досліджень у галузях освіти, педагогіки та виховання та iз урахуванням найвищих стандартів науки та принципів співпраці, соціальної справедливості, інклюзії та рівності. Студенти можуть обрати програми як на рівні бакалавру, так i на рівні магістру. Перевагою цього факультету є те, що згідно із рейтингом QS World University Rankings 2021, факультет займає 10 місце у світі [85].

До складу факультету входять чотири кафедри та дві школи:

- Кафедра педагогіки та організації освітнього процесу;

- Кафедра освітньої та консультативної педагогіки та спеціальної освіти;

- Кафедра освітніх досліджень;

- Кафедра мовної підготовки.

- Школа кінезіології

- Школа педагогіки в Оканаган.

В основі діяльності кафедри педагогіки та організації освітнього процесу є дослідження у галузі педагогіки та методики викладання окремих дисциплін протягом усього життя, міждисциплінарні дослідження, a саме теорія навчального плану, проектування та оцінка, освіта вчителів, цифрові медіа та технології навчання, навчальна програма та педагогіка у вищій школі, організація навчання в неформальних освітніх умовах. Кафедра пропонує низку програм як на рівні магістру, акт і на рівні доктора філософії, більшість з яких структуровано як дослідницькі тематичні когорти.

Крім того, викладачами кафедри розробляються та проводяться літні програми підвищення кваліфікації вчителів, які розраховані на 3-6 кредитів та тривають один -два тижні в залежності від програми. Зокрема, такі програми присвячені удосконаленню у галузі викладання мистецтва, математики, фізичного виховання та технологій [86]. 
В основі діяльності кафедри освітньої та консультативної психології та спеціальної освіти полягають програми використання та застосування психологічних основ та дослідження для розуміння та вирішення проблем особистості протягом усього життя та в різних контекстах, зокрема сім'ї, громади, школи та робочих місць. Під час роботи зі студентами викладачі надають перевагу поєднанню практики та досліджень, тісно співпрацюючи зі школами, громадськими організаціями та політиками. На кафедрі створено умови для плідної співпраці як студентів між собою, так і викладачів та студентів.

Вибір освітніх програм $є$ також досить широким: консультативна психологія; розвиток людини, навчання та культура; методологія та оцінювання дослідження; шкільна та прикладна психологія дитини; спеціальна освіта; орієнтація та мобільність Причому ці програми пропонується як на рівні магістрів, так і докторів філософії [87].

Робота кафедри освітніх досліджень спрямована на розширення знань про критичні проблеми, з якими стикаються освіта, викладачі та студенти в різних контекстах. Професорсько-викладацький склад кафедри намагається створити умови для навчання, які трансформують і підтримують життєві цілі студентів. Освітні програми спрямовані на формування лідерства у різних сферах освіти, підготовку до роботи з корінним населенням, навчання протягом усього життя, контексту освіти K-12, політики та управління у галузі вищої освіти, а також культурні, історичні, соціологічні, політичні та філософські основи освіти [88].

Кафедра мовної підготовки є лідером у своїй галузі та пропонує до уваги студентів такі освітні програми як викладання мов в багатомовному, багатокультурному та мультимодальному контекстах; цифрові медіа, культури та технології в мовній та освітній грамотності; навчання на основі мистецтва, літератури та мови; корінна мова та навчання грамоті; критичні та фасілітуючи підходи до навчання грамоті та мовної освіти; теорії та методології дослідження грамоти та мовної освіти [89]. 
При школі кинезіології студенти мають змогу вивчати рухи людини, особливості іï фізичної активності та спорту та їх впливу на здоров'я, працездатність та якість життя. Дослідження та викладання в кінезіології розглядають рух людини з різних точок зору в межах анатомії, фізіології, біомеханіки, спортивної медицини, психології, соціології та гуманітарних наук. Школа заохочує до участі у фізичній активності через свої програми та спонукає вести активний спосіб життя для підтримки розвитку здорових людей, груп і суспільств.

Диплом з кінезіології дозволяє працювати у різних сферах, таких як освіта, фітнес та відпочинок, спортивний менеджмент, медицина, фізіотерапія та харчування. Випускники-кінезіологи можуть працювати в школах, університетах, лікарнях, військових середовищах, готелях, центрах відпочинку, спортивних клубах, водних закладах, клініках, оздоровчих центрах та інших приватних і державних установах [90].

Школа педагогіки в Оканаган пропонує здобувачам освіти як програми на рівні бакалавру та магістру, так і освітні програми з підвищення кваліфікації вчителів, які вже працюють.

Зокрема, у рамках послідовної моделі навчання студентам пропонують курс навчання тривалістю 16 місяців з такою спеціалізацією: робота 3 дітьми у віковому діапазоні від 5 років до п'ятого класу та робота із підлітками шостого - дев'ятого класів. Велика увага у рамках цієї освітньої програми приділяється набуттю практичних знань та умінь. Так, студенти обов'язково проходять 15 тижнів практики під керівництвом досвідчених педагогів [91].

Магістерські програми 3 педагогіки пропонують студентам можливість розвивати спеціалізовані сфери інтересів та інтегрувати свою практику в рамках досліджень і індивідуальної траєкторії. Освітні програми призначені для вчителів, координаторів предметних областей, адміністраторів освіти, нетрадиційних педагогів та дослідників у сфері позашкільної освіти.

Здобувачі освіти разом зі своїми науковими керівниками розробляють програми, які однозначно відповідають їхнім інтересам і цілям, обираючи курси, 
які охоплюють такі основні теми: планування та організація освітнього процесу, цифрове навчання, різноманітність та освітнє лідерство та політика. I магістр освіти, і магістр мистецтв в галузі освіти розраховано на 30 кредитів навчального навантаження; кожна освітня програма надає студентам теоретичний, практичний та аналітичний досвід, а також місце в спільноті вчених-практиків, присвячених організації навчання протягом усього життя [91].

У провінції Онтаріо також існує професійна асоціація, яка регулює педагогічну освіту. Педагогічний коледж Онтаріo (Ontario College of Teachers) було створено у 1994 році. До його основних видів діяльності також належить розробка етичних стандартів для вчителів та настанов для молодих учителів. Необхідно зазначити, що тільки в Онтаріо є Рада з забезпечення якості вищої освіти (Higher Education Quality Council of Ontario). Її було створено відповідно до Закону про Раду з якості вищої освіти у 2005 р. як незалежного представництва уряду Онтаріо для аналізу та покращення доступу, якості та звітності відділу вищої освіти, а також для розробок рекомендацій щодо покращення вищої освіти в провінції. Рада забезпечення якості вищої освіти також здійснює перевірку якості освітніх програм педагогічних університетів та розподіляє фінансування для проведення науково-дослідної роботи на базі провінції $[84$, с. 76$]$.

На території провінції Онтаріо представлено 7 програм педагогічних університетів, що підтверджується сертифікатом або ступенем бакалаврата, магістратури та аспірантури 3 педагогіки. Педагогічним факультетом Університету Західного Онтаріо пропонується загальна наукова програма 3 педагогіки, а Університет Ніпісінга запрошує взяти участь у педагогічній школі ім. Шуліха за спеціалізацією: «Викладання і педагогіка». Решта педагогічних університетів запрошує до більш вузьких програм: «Педагогіка фортепіано» або «Психологія і педагогіка фізичної активності та спорту».

Крім того, у Західному Онтаріо пропонуються курси додаткової кваліфікації (AQ), які спеціально розроблені для сертифікованих викладачів і зосереджені на навчальній програмі Онтаріо. Проходження курсів AQ може 
допомогти педагогам підвищити свої навички, розширити знання та просунути кар’єру у сфері надання освітніх послуг.

Крім того, ASPIRE пропонує курси професійного розвитку, сертифікати та семінари, які використовують досвід у різних галузях. Ці курси підвищення кваліфікації можна проходити окремо або об'єднувати для формування сертифікатів.

Університет Торонто, який є одним 3 найперших не тільки в провінції Онтаріо, а й в Канаді в цілому, пропонує кілька сотень курсів в рамках 14 факультетів; близько 2000 курсів в рамках одного тільки факультету мистецтва i науки, а також 85 докторських програм. Педагогічна освіта в Університеті Торонто представлена двома програмами: Магістр гуманітарних наук у галузі навчання дітей та освіти (МА) та Магістр викладання\навчання (MT).

Програма «Магістр гуманітарних наук у галузі навчання дітей та освіти» (МА) триває 2 роки, або 5 триместрів, i супроводжується широкою практикою викладання та плідною співпрацею із власною лабораторною школою. Кожен студент-викладач має більш, ніж 450 годин практики викладання. Випускники університету мають право подати заяву в Педагогічний коледж Онтаріо для отримання сертифіката учителя початкової або молодшої школи.

Програма Магістр викладання\навчання (MT) пропонує складне академічне середовище, спрямоване на спільну освіту у галузі педагогічної теорії та провідної педагогічної практики. Кандидати можуть вибрати за бажанням одну з програм початкових, молодших, середніх, старших класів. Програма складається 318 напівкурсів і 3 практик викладання. Більш того, практиці приділяється значна увага, адже для того, щоб стати сертифікованим вчителем у провінції Онтаріо, необхідно успішно завершити 80-денну практику. Кандидати у вчителі проходять два одномісячних блоки практики на 1-му році і розширену практику на 2-му році програми [92]. 
На відміну від провінції Онтаріо, уряд Манитоба, на думку деяких науковці, не втручається у розвиток педагогічної освіти у штаті. Для того, щоб працювати учителем в цьому штаті достатньо мати:

- 150 залікових годин з курсів післясередньої освіти , 60 з яких - курси 3 педагогіки та методики викладання;

- два наукові ступеня бакалавра мистецтва, які були отримані послідовно або паралельно;

- 30 кредитів з вивчення дисципліни, яку було обрано для викладання [93].

Разом із тим, не зважаючи на досить невелике навантаження на майбутніх фахівців, університети штату намагаються утримувати якість освіти на гідному рівні [94].

Наприклад, на факультеті педагогіки університету Манітоба існує можливість опанувати освітню програму за будь-яким рівнем освіти: бакалавр, магістр або доктор філософії. Освітні програми бакалаврського рівня передбачають обрання однієї із вікових груп: робота із дітьми дошкільного віку, робота із дітьми 5-8 класів та старших класів за однією із спеціальностей:

- робота з корінним населенням;

- інклюзивна освіта;

- міжкультурна освіта;

- технічні науки;

- іноземні мови;

- освіта для сталого розвитку.

Факультет також запрошує до магістерських програм, які є гнучкими i пропонують студентам можливість отримати ступень магістру освіти (Med), навчаючись неповний робочий день 3 численними курсами, доступними у вечірній час або літні місяці. Факультетом пропонуються наступні спеціалізації:

- освіта для дорослих та післясередня освіта;

- консультативна психологія; 
- міжкультурні, соціологічні та філософські основи освіти;

- адміністрація освіти;

- інклюзивна освіта;

- мова та грамотність;

- іноземні мови;

- дослідження в навчальній програмі, викладання та навчання [95].

На відміну від Манітоби уряд Альберти має більш практичний підхід. У цьому штаті на початку XXI століття були проведені реформи, спрямовані на формулювання та узгодження стандартів щодо знань, умінь та навичок, якими мають володіти вчителі. Велика увага також приділяється організації навчального процесу в школі, оцінюванню навчальних досягнень учнів та розробці стандартизованого тестування, яке виявляє сильні та слабкі сторони учнів та дозволяє коригувати роботу вчителя.

Відповідно до законодавства штату, міністр може бути ініціатором проведення тестування як учнів, так і учителів. Ще однією особливістю організації навчального процесу цього штату є те, що з 2006 року всі учні, починаючи з четвертого класу, розпочинають вивчати другу мову [96].

Основним факультетом, на якому здійснюється підготовка вчителів у цій провінції, є педагогічний факультет університету Альберта, який зайняв 47 місце iз 800 у світовому рейтингу університетів QS 2019 за предметами. Це найстаріший педагогічний факультет у країні, його було засновано ще у 1942 році. До складу факультету входить чотири кафедри та одна освітня школа, кожна 3 яких має свої особливості та спеціалізацію. Зокрема, в університеті працюють кафедри початкової освіти, середньої освіти, вивчення освітньої політики, педагогічної психології та школи бібліотекознавства та інформації. Диплом цього факультету визнається не тільки в країні, але й в усьому світі. Як і в інших університетах країни, здобувачам пропонуються освітні програми різних рівнів, які відповідають потребам студентів та вимогам різних освітніх контекстів. Під час викладання викладачі використовують новітні методики та освітні технології [97]. 
Разом із тим, підписання у 2006 р. між провінціями Альберти та Британської Колумбії двосторонньої згоди про торгівлю, інвестиції та мобільності робочої сили мало певний вплив на уніфікацію підходів до підготовки вчителів. У рамках цієї угоди зросла мобільність вчителів цих двох провінцій. До того ж, була розроблена форма Згоди деканів про початкову педагогічну освіту [98].

У таблиці 1 представлено узагальнену інформацію щодо вимог, які висуваються до підготовки вчителів у рівних провінціях. Зокрема узагальнено інформацію щодо сертифікації вимог у кожній провінції, механізм регулювання професійного вдосконалення педагогів, кількість закладів педагогічної вищої освіти та стандартів, які є необхідними для отримання сертифікату.

Таблиця 1

Вимоги щодо проходження сертифікації вчителів Канади

\begin{tabular}{|c|c|c|c|c|}
\hline \multicolumn{5}{|c|}{ Провінції } \\
\hline 1 & 2 & 3 & 4 & 5 \\
\hline & Альберта & $\begin{array}{l}\text { Британська } \\
\text { Колумбія }\end{array}$ & Манітоба & Онтаріо \\
\hline $\begin{array}{l}\text { Професійне } \\
\text { регулювання }\end{array}$ & $\begin{array}{l}\text { Державне } \\
\text { регулювання }\end{array}$ & $\begin{array}{l}\text { Саморе- } \\
\text { гулювання } \\
\text { (Коледж вчителів } \\
\text { Британської } \\
\text { Колумбії) }\end{array}$ & $\begin{array}{l}\text { Мінімальне } \\
\text { державне } \\
\text { регулювання }\end{array}$ & $\begin{array}{l}\text { Саморегулювання } \\
\text { (Педагогічний } \\
\text { коледж Онтаріо) }\end{array}$ \\
\hline $\begin{array}{l}\text { Вимоги до } \\
\text { сертифікації }\end{array}$ & $\begin{array}{l}\text { Постійний } \\
\text { сертифікат } \\
\text { викладання у } \\
\text { штаті не менше } \\
2 \text { років; } \\
\text { отримання } \\
\text { другої } \\
\text { педагогічної }\end{array}$ & $\begin{array}{l}\text { Сертифікація } \\
\text { Коледжем } \\
\text { вчителів } \\
\text { Британської } \\
\text { Колумбї } \\
\text { наявність } \\
\text { диплому } \\
\text { бакалавра; }\end{array}$ & $\begin{array}{l}\text { Постійний } \\
\text { сертифікат } \\
\text { Отримання } \\
\text { диплому } \\
\text { бакалавру } \\
\text { правом } \\
\text { викладання; }\end{array}$ & $\begin{array}{l}\text { Загальний } \\
\text { сертифікат } \\
\text { кваліфрікаиіi } \quad \text { ma } \\
\text { регістращії } \\
\text { Отримання } \\
\text { диплому } \\
\text { бакалавру }\end{array}$ \\
\hline
\end{tabular}




\begin{tabular}{|c|c|c|c|c|}
\hline & $\begin{array}{l}\text { освіти у штаті; } \\
\text { тимчасовий } \\
\text { сертифіка; } \\
\text { відсутність } \\
\text { педагогічного } \\
\text { стажу або } \\
\text { педагогічний } \\
\text { стаж до двох } \\
\text { років }\end{array}$ & $\begin{array}{l}\text { наявність } \\
\text { педагогічного } \\
\text { стажу; } \\
\text { рекомендація } 3 \\
\text { місця роботи, } \\
\text { характеристика; } \\
\text { базовий } \\
\text { сертифікат } \\
\text { відсутність } \\
\text { диплому } \\
\text { бакалавра, але } \\
\text { наявність } \\
\text { сертифікату } \\
\text { іншої провінції }\end{array}$ & $\begin{array}{l}\text { Тимчасовий } \\
\text { сертифікат } \\
\text { Для вчителів, } \\
\text { які отримали } \\
\text { освіту в інших } \\
\text { провінціях } \\
\text { діє три роки, } \\
\text { потім необхідно } \\
\text { оновлювати }\end{array}$ & $\begin{array}{l}\text { правом } \\
\text { викладання; } \\
\text { Право викладання } \\
\text { у певній віковій } \\
\text { категорії } \\
\text { Перехідний } \\
\text { сертифікат } \\
\text { кваліфікації та } \\
\text { регістраиії; } \\
\text { Немає профільної } \\
\text { освіти } \\
\text { Тривалість - } 6 \\
\text { років }\end{array}$ \\
\hline $\begin{array}{l}\text { Кількість } \\
\text { закладів вищої } \\
\text { педагогічної } \\
\text { освіти та } \\
\text { особливості } \\
\text { організації } \\
\text { освітнього } \\
\text { процесу }\end{array}$ & $\begin{array}{l}5 \\
\text { Послідовна та } \\
\text { паралельна } \\
\text { модель; } \\
\text { Програми } \\
\text { навчання - 12- } \\
\text { та 24-місяці } \\
\text { (послідовно) } \\
\text { •Кампус лише } \\
\text { для французької } \\
\text { мови } \\
\text { •1 } \\
\text { супутниковий } \\
\text { кампус } \\
\text { для U он Alberta } \\
\text { • } 2 \text { релігійні } \\
\text { установи }\end{array}$ & $\begin{array}{l}8 \\
\text { 12-, 16-, 18- і } \\
\text { 24-місячні } \\
\text { програми } \\
\text { (послідовна } \\
\text { модель) } \\
\text { •корінні, } \\
\text { французьські } \\
\text { програми; } \\
1 \\
\text { пелігійна } \\
\text { програма }\end{array}$ & $\begin{array}{l}4 \\
\text { Послідовна та } \\
\text { паралельна } \\
\text { модель; } \\
\text { Програми } \\
\text { навчання - 12- } \\
\text { та 24-місяці } \\
\text { (послідовно) } \\
\text { •Лише } \\
\text { французька } \\
\text { мова навчання } \\
\text { •альтернатива } \\
\text { педагогічній } \\
\text { освітня } \\
\text { програмі } \\
\text { нетрадиційної } \\
\text { школи }\end{array}$ & $\begin{array}{l}18 \\
\text { Послідовна та } \\
\text { паралельна } \\
\text { модель; } \\
\text { • 12-, 16-, 18- i } \\
\text { 24-місячні } \\
\text { програми } \\
\text { (послідовно) } \\
\text { •Включає } \\
\text { кампуси- } \\
\text { супутники } \\
\text { США(1) та } \\
\text { Австралії (1) }\end{array}$ \\
\hline
\end{tabular}

$[84$, c. 22, c. 23, c. $]$ 
Отже, можна побачити, що існують три різні підходи до управління освітою в провінціях: сильний урядовий контроль в Альберті, мінімальне державне регулювання у Манітобі та саморегулювання в Британській Колумбії та Онтаріо, згідно з яким вчителя мають право викладати за умови демонстрації певного рівня знань, умінь та навичок.

Не зважаючи на широку автономію закладів вищої освіти та різні вимоги до вчителів у провінціях, у країні функціонують структури, які аналізують та контролюють якість навчання. До таких структур належить Рада міністрів Канади, Асоціація ректорів Канади, Канадська асоціація вищої освіти та Канадську федерація викладачів.

Варто зазначити, що більшість науковців виступає за створення загальнонаціональних вимог до базової освіти педагогів. У 2006 році ректорами закладів вищої освіти було підписано угоду про базову освіту освітян з метою створення загальної нормативної бази. Основною складовою угоди було прагнення зберегти самостійність та індивідуальність кожної провінції та запобігати уніфікації та стандартизації системи освіти. Разом із тим, ця угода носить лише характер рекомендацій, тому не отримало широкої підтримки в країні [99].

Підсумовуючи, можна зробити висновок, що в Канаді склалася унікальна система педагогічної освіти, яка відрізняється різноманітністю за тривалістю підготовки та освітніми програмами, що дозволяє задовільнити потреби здобувачів освіти. У країні існує три основні моделі отримання вищої освіти (послідовна, паралельна та єдина), що також сприяє диверсифікації освітніх програм та максимально враховує освітні потреби населення. Більшість випускників педагогічних факультетів Канади вважають, що підготовка на педагогічних факультетах канадських закладів вищої освіти є сучасною, повною, грунтовною та органічно поєднує теоретичну та практичну підготовку. 